\title{
RASA PERCAYA PADA PASUTRI PERKAWINAN JARAK JAUH
}

\author{
Saira Lastiar Naibaho, \\ Stefani Virlia ${ }^{l}$ \\ Fakultas Psikologi \\ Universitas Bunda Mulia \\ Jl. Lodan Raya No. 2, Ancol \\ Jakarta Utara 14430, Indonesia \\ Iemail:swijaya@bundamulia.ac.id
}

\begin{abstract}
Couples have the responsibility in domestic life, communicating with each other, and accept any changes that occur in marital life. Physical separation between couples is severe, where the fulfillment of the task of marriage becomes ineffective because couples can't be met at all times. Trust becomes an important issue for couples with a distance apart, which can help couples maintain a household. This research is a phenomenological study, using interview techniques at the three couples aged 18-40 years who underwent commuter marriage since the beginning of the marriage with a maximum of 18 years of marriage. The results showed that trust in a commuter marriage can be seen from five aspects, such as openness, sharing, acceptance, support, and cooperate. There are two main factors that affect the subject remained with the conditions, commuter marriage is the economic factor and cultural factors that require women to take care her parents. In addition, there are other factors, such as the communication factor, the gratification of sexual needs, and marriage age.
\end{abstract}

Keywords: trust; commuter marriage; couples

Abstrak - Setiap pasangan suami istri (pasutri) memiliki pembagian tanggung jawab di dalam kehidupan rumah tangga, saling berkomunikasi, dan menerima segala perubahan yang terjadi pada pasangan sepanjang waktu di dalam kehidupan perkawinan. Akan tetapi, ada kalanya suatu keluarga tidak dapat tinggal dalam satu rumah dan hidup berdampingan setiap harinya. Perpisahan secara fisik antar pasutri merupakan suatu hal yang sangat berat, di mana pemenuhan tugas perkawinan menjadi tidak efektif karena pasutri tidak dapat bertemu setiap saat. Rasa percaya menjadi masalah penting bagi pasutri dengan jarak yang terpisah, yang dapat membantu pasutri mempertahankan rumah tangga. Penelitian ini merupakan penelitian fenomenologis dengan menggunakan teknik wawancara pada tiga pasutri dengan rentang usia 18-40 tahun yang menjalani perkawinan jarak jauh sejak awal pernikahan dengan usia pernikahan maksimal 18 tahun. Hasil penelitian menunjukkan bahwa rasa percaya dalam perkawinan jarak jauh dapat dilihat dari 5 aspek, yaitu aspek keterbukaan, saling berbagi, penerimaan, dukungan, dan bekerja sama. Terdapat dua faktor utama yang mempengaruhi subyek tetap bertahan dengan kondisi pernikahan jarak jauh yaknifaktor ekonomi dan budaya setempat yang mengharuskan subyek perempuan untuk menjaga orangtuanya yang sudah lanjut usia di tempat asal. Selain dua faktor tersebut, terdapat 
juga faktor lainnya, seperti faktor komunikasi, pemuasan kebutuhan seksual, dan usia pernikahan.

Kata kunci: pernikahan jarak jauh; kepercayaan; pasutri

\section{PENDAHULUAN}

Dewasa awal merupakan masa di mana seseorang mulai memisahkan diri dari keluarga dan mencari jati diri. Adapun tugas-tugas perkembangan yang harus dilakukan manusia dewasa awal adalah menikah atau membangun suatu keluarga, mengelola rumah tangga, mendidik atau mengasuh anak (Havighurst dalam Papalia \& Feldman, 2012). Hal ini sejalan dengan teori psikososial yang dikemukan Erik Erikson di mana dewasa muda memasuki tahap intimacy vs isolation, yaitu keintiman sangatlah penting dan individu diharapkan sudah mampu membangun hubungan yang dekat dan siap berkomitmen dengan lawan jenis (Papalia, Sterns, Feldman, \& Camp, 2007). Erikson juga mengatakan bahwa dewasa awal yang berhasil pada tahap ini akan menjalin hubungan yang intim dan aman dengan pasangannya, sedangkan mereka yang gagal dalam tahap ini akan muncul rasa keterasingan (isolasi) dan jarak dalam interaksi dengan orang lain (Santrock, 2012). Erikson mengatakan keintiman pada dewasa muda bisa diwujudkan dengan suatu komitmen dalam perkawinan (Papalia, Sterns, Feldman, \& Camp, 2007).

Dengan melakukan perkawinan, seorang dewasa awal akan membentuk suatu lembaga sosial yang disebut keluarga. Dalam perkawinan, ada empat hal yang menjadi tugas perkawinan bagi sepasang suami istri agar dapat menjaga keintiman dan keharmonisan keluarga, yaitu (1) pembagian tanggung jawab di dalam kehidupan rumah tangga, (2) komunikasi, (3) seks dalam perkawinan, dan (4) penerimaan akan perubahan yang terjadi pada pasangan sepanjang waktu di dalam kehidupan perkawinan (Bachrad, Hindin \& Thompson, dalam Elfida, 2011). Memenuhi tanggung jawab kehidupan rumah tangga dapat dilakukan dengan cara bekerja bagi seorang suami dan mengasuh anak bagi istri. Bagi kebanyakan orang, hubungan perkawinan dipandang sebagai hubungan yang sangat intim dan merupakan hubungan yang berlangsung lama bila dibandingkan dengan semua hubungan dekat yang ada (Halford, 2011). Studi menunjukkan bahwa kualitas perkawinan yang baik ditandai oleh komunikasi yang baik, keintiman dan kedekatan, seksualitas, kejujuran dan kepercayaan. Semua faktor itu sangat penting untuk menjalin relasi perkawinan yang memuaskan (Niswati, 2011). 
Idealnya setiap keluarga baru akan menjalin keintiman dan tinggal dalam satu rumah bersama keluarga inti, namun ada kalanya sebuah keluarga tidak dapat tinggal dalam satu rumah dan hidup berdampingan setiap harinya (Khairuddin, 2008). Banyak alasan yang menyebabkan sebuah keluarga tidak dapat tinggal bersama dalam satu rumah, salah satunya karena ingin mempertahankan pekerjaan yang tengah digeluti. Keadaan perkawinan seperti ini dapat disebut dengan commuter marriage atau perkawinan jarak jauh. Dalam perkawinan jarak jauh, trust dan komitmen cenderung dinilai tinggi bagi pasangan yang berhasil menegosiasikannya (Tessina, 2008). Dalam perkawinan jarak jauh ini juga diperlukan rasa percaya, kejujuran dan kesetiaan. Apabila salah satu pasangan mulai tidak jujur dan tidak percaya maka pasangan yang lain akan dengan sendirinya merasa tidak aman dan tidak nyaman (Dewi, 2013). Keberhasilan dalam perkawinan jarak jauh berdasar pada trust atau rasa percaya, dukungan dari pasangan, komitmen yang kuat pada perkawinan dan pasangan, dan komunikasi yang terbuka antara pasangan (Tessina, 2008).

Rasa percaya sendiri merupakan aspek penting dalam semua hubungan, terutama dalam hubungan perkawinan. Menurut Hendrick dan Hendrick (dalam Shenkman, 2004) rasa percaya merupakan faktor yang diperlukan untuk tercapainya hubungan yang sukses. Menurut Shenkman (2004) rasa percaya adalah persepsi seorang individu bahwa pasangannya memiliki kebaikan dan kejujuran yang besar dan serupa dengan yang ia miliki. Dewi (2013) berpendapat bahwa rasa percaya adalah komitmen yang dimiliki untuk mencapai harapan dan kepercayaan individu terhadap reliabilitas orang lain. Johnson (dalam Sharp, 2010) mengemukakan trust merupakan aspek dalam suatu proses secara terus menerus berubah serta bervariasi yang mendasari suatu hubungan. Trust merupakan faktor yang diperlukan untuk tercapainya hubungan yang sukses Adanya trust merupakan suatu keharusan yang diperlukan dalam suatu hubungan, karena suatu hubungan dibangun dari sebuah kepercayaan dan akan hancur karena kepercayaan mulai hilang (Groeschel dalam Beall, 2011). Dalam perkawinan jarak jauh, rasa percaya menjadi masalah penting bagi pasutri, karena jarak yang memisahkan membuat mereka tidak dapat saling menjaga satu sama lain, sehingga rasa percaya menjadi satu-satunya aspek yang dapat membantu pasutri mempertahankan rumah tangga (Shenkman, 2004). Individu yang dapat dipercaya (nilai trust tinggi) cenderung lebih disukai, lebih bahagia, dianggap lebih menarik oleh pasangannya, lebih mudah beradaptasi, dan dianggap sebagai orang yang paling dekat dibandingkan individu yang kurang dapat dapat dipercaya (nilai trust rendah) (Sharp, 2010).

Menurut Johnson dan Johnson (dalam Rhodes, 2002) tingkat rasa percaya dalam sebuah hubungan dapat berubah sesuai dengan kemampuan dan kemauan setiap orang untuk dapat percaya (trusting) dan dapat dipercaya (trustworthy). Dalam perkawinan jarak jauh sendiri, rasa percaya 
menjadi masalah bagi pasangan suami istri karena kurangnya intensitas bertemu, komunikasi, dan tidak saling mengetahui apa yang dilakukan oleh pasangannya di tempat yang berjauhan atau berbeda. Menurut Gross (dalam Rhodes, 2002), ada dua tipe dalam perkawinan jarak jauh, yaitu tipe penyesuaian dan tipe established. Pasutri perkawinan jarak jauh dengan tipe penyesuaian, yaitu pasutri dengan usia perkawinan masih muda, menjalani perkawinan jarak jauh di awal perkawinan dan memiliki sedikit atau tidak ada anak. Sedangkan tipe established adalah pasutri dengan usia perkawinan lebih tua (lama), dan memiliki anak yang sudah dewasa minimal berusia 18 tahun yang telah keluar dari rumah. Pasangan tipe established cenderung lebih sedikit mengalami stress dalam perkawinan jarak jauh daripada pasangan tipe penyesuaian. Kondisi ini disebabkan oleh perbedaan dalam hal dominasi masalah perkawinan. Berdasarkan fenomena tersebut, maka peneliti merumuskan masalah penelitian: "Bagaimana gambaran rasa percaya pada pasutri yang menjalani perkawinan jarak jauh tipe penyesuaian?"

\section{METODE}

\section{Partisipan}

Data penelitian diambil melalui wawancara terhadap tiga pasutri yang menjalani perkawinan jarak jauh antar kota sejak awal pernikahan. Karakteristik subjek penelitian berada dalam rentang usia 18-40 tahun dengan lama menikah maksimal 18 tahun serta memiliki sedikit anak, sesuai dengan teori tipe penyesuaian. Untuk mendukung hasil wawancara, peneliti juga melakukan observasi terhadap tiga pasutri yang menjadi subjek penelitian ini. Observasi dilakukan di Jakarta (tempat suami bekerja) dan di Brebes (tempat istri menetap).

\section{Desain}

Penelitian ini menggunakan metode penelitian kualitatif dengan jenis penelitian fenomenologis, karena penelitian ini bertujuan untuk menggambarkan suatu fenomena berdasarkan pengalaman individu (Willig, 2008) di mana pengalaman tersebut dinyatakan dalam bentuk data deskriptif berupa kata-kata tertulis atau lisan dari orang-orang dan perilaku yang dapat diamati (Poerwandari, 2011). Fokus utama dalam penelitian ini adalah pemaknaan subjek terhadap rasa percaya yang terbentuk dalam perkawinan jarak jauh.

\section{Prosedur}


Penelitian ini menggunakan 2 tahap. Tahap pertama adalah tahap persiapan, yang meliputi penyusunan pedoman wawancara; penentuan subjek penelitian dengan teknik criterion sampling karena subjek ditentukan berdasarkan kriteria yang sudah ditentukan peneliti sejak awal. Tahap kedua adalah tahap pelaksanaan, yaitu pengambilan data lapangan. Pengambilan data dilakukan di 2 daerah, yaitu di Jakarta (tempat suami bekerja) dan Brebes (tempat istri menetap). Tahap pengolahan data dilakukan setelah data wawancara telah terkumpul.

\section{Instrumen}

Teknik pengumpulan data menggunakan teknik wawancara terhadap subjek penelitian. Panduan wawancara mengacu pada teori Johnson dan Johnson (dalam Fukuyama, 1996; dalam Shenkman, 2004) yang mencakup lima aspek pembentuk rasa percaya yaitu aspek keterbukaan, saling berbagi, penerimaan, dukungan, dan niat bekerjasama. Berdasarkan teori tersebut, maka konsep operasional penelitian ini adalah:(1) Aspek keterbukaan: kesediaan membagi informasi, ide, perasaan, pikiran, dan reaksi mengenai isu-isu yang terjadi; (2) Aspek saling berbagi: menawarkan bantuan kepada pasangan untuk membantu penyelesaian masalah atau tugas; (3) Aspek penerimaan: komunikasi dan menghargai pendapat pasangan; (4) Aspek dukungan: bentuk kepercayaan terhadap kemampuan pasangan; (5) Aspek niat bekerjasama adalah harapan dan tindakan untuk saling bekerja sama untuk mencapai pemenuhan tujuan.

Pedoman wawancara penelitian mengacu pada kelima aspek di atas. Berikut adalah contoh pertanyaan untuk tiap aspek:

Tabel 1.

Pertanyaan per Aspek

Aspek Pertanyaan

Bentuk komunikasi apa yang sering anda gunakan untuk berkomunikasi dengan pasangan?

Aspek Keterbukaan

Apa saja yang anda dan pasangan anda bicarakan ketika sedang berjauhan ? Bagaimana cara Anda mengatasi permasalahan tersebut?

Aspek Saling Permasalahan seperti apa yang biasa dihadapi dalam perkawinan jarak jauh ini ?

Berbagi Apabila pasangan anda sedang mengalami masalah saat sedang berjauhan, apa yang anda lakukan untuk membantu meringankan masalahnya ?

Bagaimana anda menyikapi komunikasi yang terbatas saat sedang berjauhan?

Aspek Penerimaan $\quad$ Apa perbedaan perasaan yang anda rasakan saat tinggal bersama dan saat sedang berjauhan dengan pasangan anda?

Aspek Dukungan $\quad$ Apa yang membuat anda bertahan dalam perkawinan jarak jauh ini ?

Bagaimana anda menilai kemampuan pasangan anda dalam menjalani tugas-tugasnya sebagai istri/suami? 
Aspek Niat Apabila sedang bersama di rumah kegiatan apa yang anda dan pasangan anda lakukan?

Kerjasama Coba ceritakan bagaimana pembagian tugas yang anda dan pasangan anda lakukan?

Selain menggunakan teknik wawancara, peneliti juga melakukan observasi terhadap subjek selama proses wawancara berlangsung, di mana observasi ini bertujuan untuk melihat komunikasi non verbal yang ditunjukkan oleh subjek selama wawancara dan interaksi subjek dengan peneliti selama proses tersebut.

\section{Teknik Analisis}

Hasil wawancara diubah dalam bentuk verbatim, kemudian dianalisis dan diinterpretasi dengan teknik content analysis, yang terdiri dari tiga tahap yaitu melakukan koding, menentukan tema, dan menganalisis menurut teori dasar (Patton, 2002). Kredibilitas dalam penelitian ini dapat ditingkatkan dengan melakukan triangulasi sumber data, yaitu melakukan menggunakan variasi sumber-sumber data yang berbeda (Poerwandari, 2011). Dalam penelitian ini, triangulasi dilakukan dengan melakukan wawancara alloanamnesa terhadap orang-orang yang mengenal dan dianggap cukup dekat dengan subjek, yakni adik kandung subjek, ibu mertua subjek, ibu angkat subjek, dan teman kerja subjek.

Analisis data menggunakan teori trust dari Johnson dan Johnson (dalam Fukuyama, 1996; dalam Shenkman, 2004). Sementara proses intepretasi dilakukan dalam beberapa tahap. Tahap pertama, melakukan identifikasi terhadap tema-tema yang muncul pada setiap responden berdasarkan dimensi trust, yaitu keterbukaan, saling berbagi, penerimaan, dukungan, serta niat bekerja sama. Tahap ke dua, membuat tabel perbandingan (persamaan maupun perbedaan) antar pasutri. Tahap ke tiga, mengambil kesimpulan dari dinamika ketiga data subyek tersebut.

\section{ANALISIS DAN HASIL}

Peneliti akan menjelaskan analisis dan hasil penelitian berdasarkan subjek yang merupakan pasangan suami istri dengan perkawinan jarak jauh, yakni Subjek 1, Subjek 2 dan Subjek 3. Tiap subjek akan memuat analisis data di lapangan berdasarkan konsep operasional penelitian. 


\section{Subyek 1}

Tabel 2.

Identitas Subyek 1

\begin{tabular}{lll}
\hline \multicolumn{1}{c}{ Keterangan } & \multicolumn{1}{c}{ Suami } & Istri \\
\hline Inisial & S & EY \\
Jenis Kelamin & Laki-laki & Perempuan \\
Usia & 29 tahun & 28 tahun \\
Agama & Islam & Islam \\
Asal & Desa Kubang Pari, Brebes. Desa Kubang Pari, Brebes. \\
& Jawa Tengah & Jawa Tengah \\
Pendidikan Terakhir & Sekolah Dasar & Sekolah Menengah Atas \\
Pekerjaan & Buruh konveksi mabel & Ibu rumah tangga \\
Tempat bekerja & Klender, Jakarta Timur & \\
Status & & Menikah \\
Lama menikah & & Lima tahun \\
Jumlah anak & & Satu orang \\
\hline
\end{tabular}

Subjek 1 menikah pada tahun 2010 dan memiliki seorang anak laki-laki berusia 4 tahun. Suami (S) bekerja sebagai buruh di salah satu konveksi pembuatan sofa di Jakarta timur, sedangkan istri (EY) berada di kota asal (Brebes, Jawa Tengah), berjualan rujak dan ‘jajanan’ anak-anak di depan rumahnya. Subjek 1 telah menjalani perkawinan jarak jauh selama 5 tahun sejak awal perkawinan. Ekonomi menjadi faktor yang membuat subjek harus menjalani perkawinan jarak jauh. Subjek menganggap sulit mendapatkan pekerjaan di kota asal sehingga $\mathrm{S}$ terpaksa harus bekerja di Jakarta untuk menunjang kehidupan EY dan anaknya. Selain faktor ekonomi, ada juga faktor budaya setempat yang mengharuskan istri untuk menetap di kota asal dan tidak ikut suami ke luar kota asal (Jakarta). Adat istiadat setempat mengharuskan anak perempuan untuk merawat dan menjaga orang tuanya di masa tuanya.

EY memiliki keinginan besar untuk ikut S ke Jakarta namun ada perasaan takut akan menambah beban suaminya. Pada saat yang sama, EY memiliki kewajiban untuk merawat orangtuanya, sehingga EY tidak pernah mengutarakan keinginan ini langsung ke S. Hal serupa juga dirasakan oleh S yang merindukan kehadiran EY karena seringkali merasa kelelahan harus bekerja sekaligus mengurus dirinya sendiri.

$\mathrm{S}$ dan EY diwawancarai secara terpisah. S terlihat gugup dan takut bahkan sempat melakukan penolakan untuk dilakukan perekaman hasil wawancara namun setelah satu jam terjadi obrolan singkat di antara peneliti dengan subjek, subjek pun menyetujui untuk direkam. Begitu pula dengan EY yang merasa gugup ketika melakukan proses wawancara dengan subjek, dan sempat beberapa kali merasa 
bingung dengan pertanyaan yang diajukan sehingga peneliti perlu mengulang kembali beberapa pertanyaan. Namun, baik S dan EY terbuka dalam mengemukakan pikiran dan perasaannya terhadap peneliti. Hal ini terlihat dari ekspresi wajah $\mathrm{S}$ yang terlihat sedih dan seperti menahan air mata ketika menjawab pertanyaan peneliti mengenai alasan tidak membawa anak dan istrinya ke Jakarta. Hal serupa juga dirasakan oleh EY, ia menangis ketika menceritakan alasannya tidak dapat ikut dengan suaminya ke Jakarta, ia merasa bahwa hal tersebut adalah hal paling berat yang harus ia terima. Ketika menceritakan mengenai dukungan suami/istri, baik S maupun EY terlihat tersenyum dan bersemangat menceritakan pengorbanan yang sudah dilakukan untuk terus mempertahankan pernikahan mereka.

Aspek Keterbukaan.Menurut Johnson dan Johnson (dalam Fukuyama, 1996) keterbukaan adalah kesediaan membagi informasi, ide-ide, pemikiran, perasaan dan reaksi mengenai isu-isu yang terjadi. Saat tinggal di Jakarta, S selalu menceritakan semua hal kepada EY. S juga selalu meminta izin dan restu dari istrinya setiap kali ingin mengambil suatu keputusan. Pada sisi lain, EY cenderung menyembunyikan setiap masalah karena ingin menjaga perasaan S. EY selalu memilah-milah topik pembicaraan dengan S. Apabila masalah yang ia hadapi tidak menyangkut hubungan baik antara keluarganya dan suaminya, EY selalu menceritakannya kepada suaminya dengan apa adanya.

“..Iya selalu cerita, gak ada yang ditutup-tutupin” (S)

“..kalo misalnya enggak parah-parah banget sih biasanya suka apa adanya cerita, selalu cerita sama suami masalah apa-apa tapi kecuali kalo masalah yang menyangkut keluarga saya.." (EY)

Aspek Saling Berbagi. Menurut Johnson dan Johnson (dalam Fukuyama, 1996), saling berbagi yaitu menawarkan bantuan material dan sumber daya kepada orang lain dengan tujuan untuk membantu pihak lain guna penyelesaian tugas. Apabila $\mathrm{S}$ sedang memiliki masalah dengan mertuanya, EY selalu memberikan nasehat dan dukungan serta membantu mencari jalan keluar dari masalah yang terjadi. Sebaliknya, S juga selalu memberikan nasehat dan solusi atas permasalahan yang dihadapi EY.

“..kita ada masalah sama keluarga sama mertua apa, kita selalu kasih nasehat, kita selalu cari jalan tengahnya” $(S)$

“..kalo saya yang lagi emosi dia bisa ngademin, trus sebaliknya kalo dia lagi emosi saya juga bisa ngademin.." (EY) 
Aspek Penerimaan. Menurut Johnson dan Johnson (dalam Fukuyama, 1996) penerimaan adalah melakukan komunikasi dengan orang lain dan menghargai pendapat mereka tentang suatu hal yang sedang dibicarakan atau dilakukan. S tidak mengalami perbedaan komunikasi dengan EY baik pada saat berjauhan maupun pada saat bersama. S juga sangat bersyukur karena EY menerima semua hal yang ia lakukan, dan tidak pernah menuntut apapun darinya.

“Kita sering ngabarin aja, kabarin sms apa, pokoknya pas saya ada pulsa, saya ngabarin, saya gak ada pulsa bini di kampung yang telpon. Saling komunikasi aja”...

“Alhamdulillah kalo istri saya, dia gak pernah menuntut.." (S)

Aspek Dukungan. Menurut Johnson dan Johnson (dalam Fukuyama, 1996), dukungan adalah suatu kepercayaan bahwa orang lain mempunyai kapabilitas yang dibutuhkan dalam suatu kegiatan. S merasa bahwa EY cukup mampu menjalankan tugas sebagai ibu. EY juga ikut membantu perekonomian keluarga dengan membuka warung kecil di depan rumahnya. EY merasa bahwa S sangat kompeten dalam bidang menjahit sofa. EY selalu mendukung S untuk tetap bekerja di bidang menjahit sofa dan memperdalam ilmu di bidang tersebut.

“..yang saya tahu emang dia maksudnya ahli lah dibidang itu misalnya pindah profesi, ganti profesi kayaknya kurang.." (EY)

Aspek Niat Bekerjasama. Menurut Johnson dan Johnson (dalam Fukuyama, 1996), niat bekerjasama adalah harapan bahwa seseorang dapat bekerjasama dan bahwa orang lain juga dapat bekerjasama untuk mencapai pemenuhan tujuan. Dalam satu bulan, $\mathrm{S}$ hanya bertemu dengan keluarganya satu kali karena hanya mendapat izin pulang selama dua hari. Apabila sedang berada di rumah, $\mathrm{S}$ selalu membantu apa pun pekerjaan yang dibutuhkan, seperti membantu menjaga anak, membantu mengurus sawah, membantu panen padi, juga menjemur dan menggiling padi.

“..pas ada kalo saya ada di kampung, bareng-barenglah jaga anak itu barengbareng, bareng-bareng ngasuh anak, siapa aja ya, misalnya saya lagi senggang, istri lagi masak apa, ya udah anak kita saya mandiin...” (S) 


\section{Subyek 2}

Tabel 3.

Identitas Subyek 2

\begin{tabular}{lll}
\hline \multicolumn{1}{c}{ Keterangan } & \multicolumn{1}{c}{ Suami } & Istri \\
\hline Inisial & T & SD \\
Jenis Kelamin & Laki-laki & Perempuan \\
Usia & 34 tahun & 32 tahun \\
Agama & Islam & Islam \\
Asal & Desa Cikandang, Brebes. Jawa & Desa Cikandang, Brebes. Jawa \\
& tengah & tengah \\
Pendidikan Terakhir & SMP & SD \\
Pekerjaan & Messenger dan Driver & Pedagang \\
Tempat bekerja & Mampang, Jakarta Selatan & Brebes, Jawa Tengah \\
Status & & Menikah \\
Lama menikah & & 8 tahun \\
Jumlah anak & & Satu orang \\
\hline
\end{tabular}

$\mathrm{T}$ dan SD diwawancarai secara terpisah. $\mathrm{T}$ terlihat tenang dan terbuka dalam menjawab setiap pertanyaan dari peneliti. T menunjukkan ekspresi yang sama dan tidak berubah-ubah. Ia hanya terlihat malu-malu saat menceritakan konflik yang sering terjadi dengan istrinya, bahkan sesekali tertawa ketika menceritakan kecurigaan istrinya terhadap dirinya. Berbeda dengan T, SD menunjukkan ekspresi yang sedih dan menangis ketika menceritakan kesepian yang dirasakannya ketika sedang tidak bersama suaminya. Ekspresi wajah SD mulai berubah dan tersenyum ketika menceritakan dukungan yang diberikan suaminya terhadap dirinya.

Aspek Keterbukaan. T bicara bercerita masalah pekerjaan kepada SD, namun berusaha menyembunyikan hal-hal yang sekiranya dapat menimbulkan konflik antara mereka. Hal ini karena SD seringkali cemburu dan menuduh $\mathrm{T}$ melakukan hal-hal yang dapat mengecewakan SD, seperti perselingkuhan. Alasan itulah yang kemudian membuat T tidak terbuka atau tidak menceritakan semua kegiatannya kepada SD.

"Masalah kerjaan, misalnya kan kalo ada kerjaan urusan kemana-mana, ntar di kirain istri tu kalo saya jelasin kadang suka gak percaya, jadi aku tu udah kalo misalnya gak pulang kalo ada acara orang-orang kantor jadi saya mending diam, soalnya kalo pas saya ceritain ntar saya dikirain nya macem-macem” (T) 
Aspek Saling Berbagi. T merasa pernah hampir menyerah untuk menjalani perkawinan jarak jauh karena rindu berkumpul bersama keluarganya. Namun, SD selalu menyemangati T bahwa masih ada harapan yang masih belum tercapai dan hal ini yang membuat $\mathrm{T}$ tetap bertahan dan menerima kondisi perkawinan jarak jauh yang mereka jalani.

"Ya kayaknya susah jauh dari keluarga, lagian juga di sana belum punya rumah, kepengenannya punya rumah di kampung aja” (T)

“..Ya memaklumi keadaan aja.. sekarang kan kita karna kebutuhan, ya mencari modal dulu lah di Jakarta gitu.. ” (SD)

Aspek Penerimaan. Konflik yang biasa terjadi antara T dan SD adalah terkait kebiasaan T dalam menjalin hubungan pertemanan dengan lawan jenis. SD selalu memeriksa handphone $\mathrm{T}$ dan sering mendapati riwayat obrolan antara $\mathrm{T}$ dan beberapa teman wanita yang sedikit mesra dan menggunakan panggilan-panggilan yang menurut $\mathrm{T}$ biasa diucapkan di Jakarta. Sementara SD menganggap bahwa panggilan tersebut berlebihan jika untuk teman biasa. Hal inilah yang membuat $\mathrm{T}$ dan SD bertengkar. Bukan hanya mencurigai, SD juga sering menuduh T melakukan perselingkuhan apabila telah selesai membaca riwayat obrolan $\mathrm{T}$ dengan teman perempuannya di handphone. Hal yang biasa T lakukan agar SD tidak mencurigainya lagi adalah dengan cara meminta SD untuk menanyakan langsung kepada teman perempuannya, setelah itu SD mulai bisa untuk percaya dan tidak membicarakan hal tersebut apabila teman perempuan $\mathrm{T}$ menjelaskan hubungan mereka hanya sebatas pertemanan.

“..Karena ya apa ya, ya kan istri kan gak tahu kalo ada temen-temen saya kan cewek disini yang di Jakarta kan fulgar dalam hal, eh say gitu...setelah baca di hp aku pas ada sms, mas lagi di Jakarta atau dimana? Dia kan langsung timbul curiga” (T)

"Saya kadang suka tertutup nggak mau kasih tahu, takutnya kalo dia ngasih tahu ntar dia nya jadi stres juga kan, biar aku aja, selagi aku masih bisa handle.." (T)

Aspek Dukungan. SD tidak pernah mempermasalahkan jarak yang terjadi antara ia dan suaminya karena sebelum menikah $\mathrm{T}$ telah mengatakan dengan jujur apa pekerjaan dan tempatnya bekerja. $\mathrm{T}$ juga sudah memberitahu resiko yang akan mereka hadapi apabila menikah jarak jauh. $\mathrm{T}$ juga sangat mendukung suaminya untuk bekerja di Jakarta dibandingkan di kampung halaman. SD merasa 
bahwa suaminya merupakan sosok pemimpin keluarga yang ia butuhkan, karena SD adalah pribadi yang tidak bisa mengambil keputusan. T juga selalu membantu SD memecahkan masalah yang ia hadapi, membantu perekonomian keluarga, membantu mengasuh dan mendidik anak. SD merasa bahwa anaknya lebih patuh kepada $\mathrm{T}$ dibandingkan kepada dirinya. Anak mereka juga sangat mengharapkan T pulang dan selalu menanyakan kapan T pulang pada SD.

“..soalnya dia tu sosok pemimpin yang aku butuhin, aku juga orangnya gak bisa ambil keputusan, lembek, jadi kalo ada dia kayak dilindungi aja, Ais juga selalu nurut sama Ayah” (SD)

“...kalo dibidang pekerjaannya mencukupilah bagus Ayah di kerjaan, apa aja dia kerjain. Ini sih ra, dia orang nya rajin..” (SD)

Aspek Niat Bekerjasama. Apabila sedang berada di rumah, $\mathrm{T}$ selalu membantu apapun pekerjaan yang memerlukan bantuannya, seperti membantu menjaga anak, membereskan dan membersihkan rumah, juga membantu orangtua SD membuat tempe di pabrik tempe milik keluarga SD. SD sendiri tidak pernah meminta bantuan $\mathrm{T}$ untuk mengerjakan tugas-tugas di rumah, tetapi $\mathrm{T}$ tetap saja mengerjakan pekerjaan di rumah tanpa perlu diminta.

“..Ya dia sih apa juga dibantuin kadang kalo aku lagi jualan pas aku pulang rumah udah beres, ya suka mandiin burung sama-sama, bersihin kandangnya, gitu aja paling. Paling nyuci..Ya kadang dia juga bantu bapak aku bikin tempe disana,"

\section{Subyek 3}

Tabel. 4.

Identitas Subyek 3

\begin{tabular}{|c|c|c|c|c|}
\hline Keterangan & \multicolumn{2}{|l|}{ Suami } & \multicolumn{2}{|l|}{ Istri } \\
\hline Inisial & $\mathbf{J}$ & & $\mathrm{K}$ & \\
\hline Jenis Kelamin & Laki-laki & & Perempuan & \\
\hline Usia & 38 tahun & & 36 tahun & \\
\hline Agama & Islam & & Islam & \\
\hline Asal & $\begin{array}{l}\text { Desa Kubangpari, } \\
\text { Jawa Tengah }\end{array}$ & Brebes. & $\begin{array}{l}\text { Desa Kubangpari, } \\
\text { Jawa Tengah }\end{array}$ & Brebes. \\
\hline Pendidikan Terakhir & SMA & & SD & \\
\hline Pekerjaan & Pedagang & & Pedagang & \\
\hline $\begin{array}{l}\text { Tempat bekerja } \\
\text { Status }\end{array}$ & Buncit, Jakarta Selatan & Mer & $\begin{array}{l}\text { Brebes, Jawa Tengah } \\
\text { kah }\end{array}$ & \\
\hline
\end{tabular}


Lama menikah

Jumlah anak
17 tahun

Tiga orang

J dan $\mathrm{K}$ diwawancarai secara terpisah. $\mathbf{J}$ menunjukkan gestur yang sedikit kaku dan terbilang monoton, intonasi dan nada bicaranya pun sedikit kaku dan datar. J terlihat sangat bersemangat saat mengungkapkan harapan-harapannya terhadap perkawinan jarak jauh yang ia dan istrinya jalani. J sesekali terlihat murung dan menarik nafas panjang saat ia menceritakan kesalahan-kesalahan yang telah ia perbuat kepada istrinya. Setelah selesai wawancara, J kembali mengingatkan peneliti agar tidak menceritakan kepada siapapun semua hal yang $\mathrm{J}$ jelaskan kepada peneliti dan ia juga menawarkan diri untuk diwawancara kembali apabila peneliti membutuhkannya. Berbeda dengan J, K terlihat kesulitan dalam menjawab pertanyaan mengenai identitas dirinya, usia anak-anaknya, usia suaminya, dan usia $\mathrm{K}$ sendiri, hal itu dikarenakan $\mathrm{K}$ lemah dalam hal hitung-hitungan. $\mathrm{K}$ menjawab setiap pertanyaan secara berbelit-belit dan terkadang tidak berhubungan dengan pertanyaan yang diajukan, sehingga peneliti berusaha mengarahkan K. K sesekali terdiam dan tampak berpikir keras (terlihat dahinya mengerut) untuk mencerna setiap pertanyaan yang diberikan peneliti, setelah peneliti mengulang kembali pertanyaan ke bahasa yang lebih sederhana akhirnya $\mathrm{K}$ bisa menjawab pertanyaan yang peneliti berikan. $\mathrm{K}$ berbicara dengan intonasi suara yang sangat pelan dan lambat. K memperlihatkan ekspresi yang bahagia sambil tersenyum saat menceritakan keharmonisan rumah tangganya dengan suaminya dan menunjukkan bahwa ia sangat menyayangi suaminya

Aspek Keterbukaan. J selalu menceritakan semua hal kepada K, mulai dari masalah pekerjaan sampai kegiatan rutin yang ia lakukan di 'panti pijat ++' untuk menyalurkan hasrat seksualnya. J selalu meminta izin terlebih dahulu sebelum pergi ke tempat ' panti pijat++' karena $\mathrm{J}$ ingin menjaga kepercayaan K. K telah mengizinkan J pergi ke 'panti pijat ++' untuk menyalurkan hasrat seksualnya dan $\mathrm{J}$ mengatakan bahwa $\mathrm{K}$ menyetujui hal itu agar J tidak melakukan kegiatan seksual atas dasar cinta atau menikah lagi dengan perempuan lain seperti kebanyakan laki-laki lakukan apabila tinggal berjauhan dengan istrinya. Awalnya, J menolak untuk melakukan kegiatan seksual dengan orang lain selain istrinya, tetapi pertemuan dua bulan sekali sungguh menyiksa dan tidak cukup bagi $\mathrm{J}$ untuk memenuhi kebutuhan seksualnya. Hal yang dirasakan $\mathbf{J}$ ini menggambarkan apa yang dikemukakan oleh Halford (2011) bahwa dalam perkawinan jarak jauh pemenuhan kebutuhan seksual pada suami istri tidak dapat tersalurkan dengan baik. 
"kita selalu cerita apa aja, misalnya lagi gak jualan, dapat berapa, bu aku dapat Cuma 40 ribu hari ini, gitu aku selalu cerita. Ya sampe aku ke panti pijat aku cerita, bu aku pergi dulu, bu aku udah pulang..” (J)

"Ya kadang mau gak mau ya aku harus ikhlas kalo suamiku jajan atau apa, asalkan dia gak kawin lagi aja itu aja”, $(K)$

Aspek Saling Berbagi. J juga selalu berusaha untuk membantu setiap permasalahan yang K alami, karena K selalu menceritakan setiap masalah yang ia hadapi kepada J. Masalah yang biasa K alami adalah masalah pertengkaran dengan tetangga. $\mathrm{J}$ selalu membantu $\mathrm{K}$ dengan cara menasehati istrinya agar tidak memperbesar masalah/konflik dengan cara diam dan tidak membalas perbuatan tetangganya. J juga selalu menelepon K pada saat mereka sedang berjauhan dan ia tidak akan berhenti menghubungi K sampai permasalahan yang dihadapi K selesai.

“Aku sih seringnya telpon mbak, ya aku nasehatin lewat telpon, pokoknya tak telpon sampe masalahnya selesai” $(J)$

"Ya gitu kadang konflik sama keluarga juga suami malahan ya udah gak papa sabar aja, bukannya marahin kakak saya atau apa enggak, malah berusaha tenangin saya” (K)

Pada sisi lain, istri $\mathbf{J}$ juga memberikan bantuan kepada setiap permasalahan yang $\mathbf{J}$ hadapi. $\mathbf{J}$ biasa menceritakan permasalahannya, seperti saat sakit, J menelepon K dan K memberikan resep jamu dan obat-obatan tradisional. K juga meminta J untuk beristirahat total saat sakit.

"Ya pernah, kayak aku sakit dia yang saranin beli jamu apa, aku puyeng dia suruh istrahat gitu" $(J)$

Aspek Penerimaan. J merasa sangat senang karena $\mathrm{K}$ selalu memberikan semangat saat J hampir menyerah dalam mencari nafkah. $\mathrm{K}$ tidak pernah menuntut $\mathbf{J}$ harus memiliki penghasilan yang banyak dan tidak pernah mempermasalahkan soal uang. K bahkan mau membantu keuangan keluarga dengan berjualan. J juga sangat bersyukur karena K sangat menerima keadaan yang J alami. Selain itu, J juga selalu menguatkan K yang terkadang mengeluh dengan pernikahan jarak jauh mereka. 
“dia gak pernah bikin masalah kalo soal duit, saya gak ada duit dia yang bantu.

Gitu mbak." (J)

Cara $\mathrm{J}$ dan $\mathrm{K}$ mengatasi jarak yang berjauhan agar bisa saling menerima keadaan adalah dengan cara saling menjaga komunikasi agar tidak terputus dan selalu saling memberi kabar satu sama lain setiap ingin pergi atau melakukan suatu aktivitas. Selain itu, mereka juga selalu beribadah dan berserah kepada Tuhan dengan keadaan yang ia dan istrinya alami

"Ya saya telpon, sholat, berserah aja sama Allah, nanti juga ada masanya kita sama-sama lagi." $(J)$

Aspek Dukungan. J dan K saling memberikan dukungan dengan sama-sama bekerja agar dapat membantu keuangan keluarga. Baik $\mathbf{J}$ maupun $\mathrm{K}$ tidak pernah memiliki rasa saling curiga satu sama lain karena mereka percaya bahwa keadaan perkawinan jarak jauh yang mereka jalani semata-mata karena kondisi ekonomi dan keadaan K yang harus menjaga orangtuanya.

“enggak pernah sih, saya percaya istri niatnya baik” (J)

"Sama-sama saling membantu, makanya saya jualan. Sekarang kehidupan keras mbak kalo kitanya suami lagi nganggur gak ada duit gimana? Gitu kan namanya orang di Jakarta gak usah terus ada sakitnya dagang ada sepinya gitu. Kayak gitu, akunya yang menyadari gitu..” $(K)$

J juga merasa sangat mencintai $\mathrm{K}$ yang selalu bersedia membantunya dalam keadaan yang sesulit apapun. Empat tahun lalu, J pernah mengalami stroke ringan yang menyebabkan ia tidak bisa mencari nafkah selama dua tahun, tapi K yang kemudian bersedia berjualan mie ayam untuk menopang kehidupan sehari-hari.

"sempat aku dua tahun gak kerja, dapat dari mana bisa sampai hidup? Ya istriku kerja jualan bantuin aku gantiin aku cari nafkah" (J)

\section{Aspek Niat Bekerja Sama}


Kegiatan yang biasa J lakukan dengan K ketika mereka sedang bersama-sama di rumah adalah membantu pekerjaan rumah tangga, seperti membersihkan rumah. J juga membantu mengajarkan anakanaknya saat mereka mengerjakan tugas dari sekolah.

"Iya mbak, kita sih lebih sering di rumah ngabisin waktu, kalo di rumah ya ngajar anak ngaji, bantuin buat PR, ya apa aja lah saling bantu. ” (J)

J dan K saling bekerjasama dalam mencari nafkah, mengurus anak dan pekerjaan rumah tangga, serta tugas-tugas lainnya. Baik $\mathrm{J}$ maupun $\mathrm{K}$ mengetahui tugasnya masing-masing dalam kehidupan perkawinan mereka. J bertugas untuk mencari nafkah yang juga dibantu oleh istrinya, sedangkan istrinya bertugas mengatur keuangan, mengasuh anak dan mengurus rumah.

"Ya itu kami kalo uang sama-sama, tapi lebih banyakan aku, ya dia urus anak, urus rumah lah gitu aja kita” (J)

\section{DISKUSI}

Berdasarkan hasil penelitian, faktor utama yang mempengaruhi subyek menjalani perkawinan jarak jauh adalah tuntutan ekonomi dan mempertahankan pekerjaan. Faktor lainnya adalah faktor budaya atau adat istiadat setempat yang berlaku di Brebes di mana seorang anak perempuan memiliki kewajiban untuk mengurus orang tuanya yang sudah lanjut usia. Faktor-faktor inilah yang mendorong pasutri bertahan dengan perkawinan jarak jauh.

Selama menjalani perkawinan jarak jauh, ada beberapa tantangan yang harus dilewati oleh subyek, seperti rasa kesepian, kelelahan karena harus bekerja sekaligus memgurus diri sendiri dan rumah tangga, kurangnya komunikasi, dan berkurangnya pemuasan kebutuhan seksual. Cara subyek menghadapi tantangan tersebut adalah dengan mengalihkan rasa kesepian dan keinginan seksual mereka ke aktivitas yang lain, misalnya beribadah/sholat, menonton acara televisi, mengobrol dengan teman atau tetangga, mengerjakan pekerjaan rumah tangga, dan sebagainya. Cara utama yang dilakukan oleh para pasutri untuk tetap mempertahankan perkawinan mereka adalah menjalin komunikasi yang intens dan memiliki rasa saling pengertian satu sama lainnya.

Menumbuhkan rasa percaya pada pasutri perkawinan jarak jauh bukanlah hal yang mudah. Menurut Sharp (2010), ada tiga faktor yang mempengaruhi rasa percaya pada pasutri yang menjalani 
perkawinan jarak jauh. Faktor pertama adalah perbedaan persepsi terhadap makna informasi yang disampaikan oleh suami ataupun istri. Sebagai contoh, pada subyek 2, SD mempersepsikan informasi yang diberikan $\mathrm{T}$ secara negatif sehingga muncul kecurigaan dan rasa tidak menerima pada diri SD. Dampak lainnya, $\mathrm{T}$ menjadi tidak tidak terbuka dari T kepada SD. Berbeda dengan subyek 3, K mempersepsikan kebiasaan J yang dianggap orang negatif, tetapi K mempersepsikan kebiasaan tersebut secara positif untuk menjaga kesetiaan suaminya agar suaminya tidak menikah lagi.

Faktor ke dua adalah hubungan kekuasaan, di mana rasa percaya muncul dan terjalin karena ada peran dan status sebagai suami atau istri. Faktor yang ke tiga adalah sifat dan kualitas komunikasi, di mana subyek yang menjalani perkawinan jarak jauh perlu memiliki kualitas komunikasi yang baik. Akan tetapi, studi menunjukkan bahwa kualitas komunikasi yang cenderung baik pun belum tentu dapat meningkatkan rasa percaya.

Selain ketiga faktor tersebut, ada faktor lain yang dapat mempengaruhi rasa percaya pada pasutri perkawinan jarak jauh, yaitu usia perkawinan dan penyesuaian perkawinan. Perkawinan merupakan proses adaptasi antara suami istri di mana suami dan istri mencegah terjadinya konflik serta menyelesaikan konflik dengan baik dalam proses penyesuaian diri (Prabowo, 2006). Usia perkawinan yang cukup matang dimulai pada usia perkawinan 15 tahun ke atas, di mana pasutri telah melakukan penyesuaian perkawinan yang baik (Prabowo, 2006). Pasutri perkawinan jarak jauh yang telah lama menikah juga mengalami stres yang cenderung lebih sedikit dibandingkan pasutri yang baru menikah (Gross dalam Raley, 2009).

\section{SIMPULAN DAN SARAN}

\section{Simpulan}

Secara garis besar, dua subyek penelitian belum memenuhi kelima aspek rasa percaya, terutama pada aspek keterbukaan dan penerimaan antar pasangan. Kedua aspek tersebut merupakan aspek penting individu untuk dapat mempercayai (trusting) dan dapat dipercaya (trustworthy). Ketidakpercayaan antar pasangan dapat dipengaruhi oleh beberapa faktor, antara lain penyesuaian perkawinan, kualitas komunikasi dan pengalaman dalam pernikahan yang berbeda satu dengan yang lainnya. Dalam penelitian ini juga ditemukan hanya satu subyek yang telah memenuhi kelima aspek rasa percaya, di mana usia perkawinan subyek telah mencapai 17 tahun perkawinan. Hal ini menunjukkan bahwa usia pernikahan turut mempengaruhi rasa percaya dalam perkawinan jarak jauh subyek penelitian. 


\section{Saran Teoretis}

Untuk pengembangan lebih lanjut, disarankan agar peneliti melakukan observasi subyek dengan waktu yang lebih lama di mana suami dan istri sedang bersama (bukan dalam kondisi terpisah) sehingga lebih terlihat dinamikanya. Dalam penelitian ini, peneliti hanya tinggal bersama dengan subyek istri kurang lebih selama tiga hari dan observasi juga hanya dilakukan ketika proses wawancara sehingga tidak dapat menggambarkan dinamika suami dan istri secara menyeluruh. Selain itu, peneliti juga perlu memperhatikan aspek budaya dan adat istiadat dari responden penelitian, misalnya kebiasaan atau nilai-nilai yang dijunjung oleh masyarakat setempat sehingga memaksa pasutri untuk menjalani perkawinan jarak jauh.

\section{Saran Praktis}

Bagi pasangan suami istri (pasutri) yang menjalani perkawinan jarak jauh, sebaiknya melakukan komunikasi dengan pasangan lebih intensif, serta menunjukkan sikap saling terbuka satu sama lain. Selain itu, pasangan juga sebaiknya menyelesaikan konflik dengan orang lain dan keluarga besar terlebih dahulu sehingga tidak membawa permasalahan tersebut ke dalam keluarga inti, yang mana dapat menganggu rasa percaya satu sama lain.

\section{REFERENSI}

Beall, C. (2011). Healing Your Marriage When Trust Is Broken. New York, NY: Harvest House Publizer.

Dewi, N. (2013). Commuter Marriage. Bogor: IPB Press.

Elfida, D. (2011). Penyesuaian perkawinan ditinjau dari beberapa faktor demografi. Jurnal Psikologi,7(2),190 - 214.

Fukuyama, F. (1996). Trust: The Social Virtue and The Creation of Prosperity. New York, NY: Free Press

Halford, K. (2011). Marriage and Relationship Education. New York, NY: Guilford Press

Khairuddin, H. (2008). Sosiologi Keluarga. Yogyakarta: Liberty. 
Niswati, I. (2011). Hubungan loving, kepuasan seksual, dan religiusitas dengan keharmonisan perkawinan. Jurnal Psibernetika, 4(2), 1-32.

Papalia, D.,\& Feldman, R. (2012). Experience Human Development (12th ed). New York, NY: McGraw Hill.

Papalia, D., Sterns, H., Feldman, R.,\& Camp, C. (2007). Adult Development and Aging (3rd ed). New York, NY: McGraw Hill.

Patton, M. Q. (2002). Qualitative Research \& Evaluation Methods(3rd ed). Thousand Oaks, CA: Sage. Poerwandari, K. (2011). Pendekatan Kualitatif untuk Penelitian Perilaku Manusia. Depok: LPSP3 Fakultas Psikologi Universitas Indonesia.

Prabowo, M. R. (2006). Penyesuaian Perkawinan Pada Pasangan yang BerlatarBelakang Etnis Batak dan Etnis Jawa. Ditemu kembali dari http://www.gunadarma.ac.id/library/articles/graduate/psychology/2006/Artikel_10500255.p df.

Rhodes, A. (2002). Long Distance Relationship in Dual Career Commuter Couple. Journal of Marriage and Family, 10, 398-404.

Santrock, J.W. (2012). Life-Span Development: Perkembangan Masa Hidup(13th ed). Jakarta: Erlangga.

Sharp, R. (2010). Living Trust For Everyone. New York, NY: All Worth Press.

Shenkman, M. (2004). The Completed Book of Trusts (3rd ed). New York, NY: John Wiley \& Sons.

Tessina, T. (2008). The Commuter Marriage. Fort Collins, CO: Adams Media.

Willig, C. (2008). Introducing Qualitative Research in Psychology (2nd ed.). New York, NY: McGraw-Hill. 